\title{
Did Tertullian Read Marcion in Latin? Grammatical Evidence from the Greek of Ephesians 3:9 in Marcion's Apostolikon as Presented in the Latin of Tertullian's Adversus Marcionem
}

\author{
T. J. LANG \\ University of St Andrews, St Mary's College, South Street, St Andrews, KY16 9JU, \\ United Kingdom. Email: tj15@st-andrews.ac.uk
}

\begin{abstract}
In his landmark work on Marcion, Adolf von Harnack became the first modern scholar to propose that Tertullian only knew Marcion's Gospel and Apostolikon in Latin translation. This proposition obtained early support but has been questioned in more recent years, the more common conjecture now being that Tertullian himself translated Marcion's Greek into Latin as needed. In deciding this matter, scholars have compared the citations of Marcion reproduced in Tertullian's Adversus Marcionem with corresponding Gospel and Pauline citations elsewhere in Tertullian's writings and then other extant Latin traditions. This nexus of data is then evaluated in terms of vocabulary and stylistic variation. The results of such a method are largely a matter of how one is predisposed to read the evidence. A way forward in this debate is to attend more closely to potential argumentative implications of a Latin versus Greek Vorlage and, specifically, to instances where arguments presented in Tertullian's Latin might unravel, or at least become differently interesting, if retrojected into Marcion's Greek. Tertullian's discussion in Adversus Marcionem 5,18,1 of Ephesians 3:9, a so-called locus classicus of Marcion's theology, is one such text, and one that complicates quests for a single Latin or Greek source behind Tertullian's usage.
\end{abstract}

Key words: Marcion; Apostolikon; Tertullian; Adversus Marcionem; Adolf von Harnack; Ephesians 3:9

\section{Introduction}

In his landmark work on Marcion, Adolf von Harnack became the first modern scholar to propose that Tertullian did not read Marcion's Gospel and Apostolikon in their original Greek but rather in an already prepared Latin translation. ${ }^{1}$ With respect to the Apostolikon, Harnack based this conclusion on his perception that in explicit citations of Marcion's text Tertullian's

\footnotetext{
${ }^{1}$ Adolf von Harnack, Marcion: Das Evangelium vom Fremden Gott: Eine Monographie zur Geschichte der Grundlegung der katholischen Kirche (TU 45; Leipzig: J.C. Hinrichs, 1921), $42 *-54 *, 160 *-3 *$
} 
language departs from his usual lexical, syntactical, and stylistic tendencies. ${ }^{2}$ Tertullian must then be quoting from a Latin translation not his own. This proposition obtained early support and ostensible corroboration in ongoing research, such as in Hans von Soden's comprehensive 1927 essay on Tertullian's version of Marcion's Pauline text, "Der lateinische Paulustext bei Marcion und Tertullian,"3 and then again in a 1951 article by A. J. B. Higgins on Tertullian's use of Marcion's Gospel text, “The Latin Text of Luke in Marcion and Tertullian."4 For some scholars Harnack's theory was simply regarded as a verified fact. So E. C. Blackman remarked in 1948: “That Tertullian had Marcion's Scriptures before him in Latin is proved by Harnack." Equally confident is Albertus Klijn in 1949: "One thing however does seem to stand out clearly after the investigation of Tertullian's text in Harnack's book on Marcion, namely that he quoted Marcion in a Latin translation." ${ }^{\prime 6}$ Despite

${ }^{2}$ In Harnack's own words, “Die Zitate aus dem Apostolikon...in adv. Marc. V heben sich lexikalisch, syntaktisch und stilistisch scharf von der eigenen Sprache Tert[ullian]s ab. Daher sind sie nicht von ihm frei nach dem Griechischen geformt, sondern übernommen" (Marcion [see note 1], 48*). And so he concludes, "Somit ist erwiesen, dass Tert[ullian] das Marcionitische Apostolikon lateinisch vor sich hatte" (53*).

${ }^{3}$ Hans von Soden, "Der lateinische Paulustext bei Marcion und Tertullian," in Adolf Jülicher, Rudolf Bultmann, and Hans von Soden (eds.), Festgabe für Adolf Jülicher zum 70.

Geburtstag, 26. Januar 1927 (Tübingen: Mohr Siebeck, 1927), 229-81.

${ }^{4}$ A. J. B. Higgins, "The Latin Text of Luke in Marcion and Tertullian," VigChr 5 (1951): 142.

${ }^{5}$ E. C. Blackman, Marcion and His Influence (London: SPCK, 1948), 132.

${ }^{6}$ Albertus Frederick Johannes Klijn, A Survey of the Researches into the Western Text of the Gospels and Acts (Utrecht: Kemink en Zoon, 1949), 159. 
such optimism, Harnack's theory had already met its first major challenge in the 1943 publication of Gilles Quispel's PhD thesis, De Bronnen van Tertullianus'Adversus Marcionem. ${ }^{7}$ Since Quispel's work, scepticism about Tertullian's interaction with Marcion in Latin has grown, and it seems the more widely held conjecture now is, as Quispel originally proposed, that Tertullian did in fact read Marcion in his original Greek and then translated Marcion into Latin as needed. ${ }^{8}$ Key works here are those of Dieter Roth on Tertullian's Gospel source and then John J. Clabeaux and Ulrich Schmid on Tertullian's version of the Apostolikon. $^{9}$

${ }^{7}$ Gilles Quispel, De Bronnen van Tertullianus' Adversus Marcionem (Leiden: Burgersdijk \& Niermans Templum Salomonis, 1943).

${ }^{8}$ For this approach to Tertullian's text of Marcion's Apostolikon, see Ulrich Schmid, Marcion und sein Apostolos: Rekonstruktion und historische Einordnung der marcionitischen Paulusbriefausgabe (Arbeiten zur Neutestamentlichen Textforschung 25; Berlin: de Gruyter, 1995), 40-59. For a similar view on Tertullian's version of Marcion's Gospel, see Dieter T. Roth, "Did Tertullian Possess a Greek Copy or Latin Translation of Marcion’s Gospel?," VigChr 63 (2009): 429-67. For summaries of scholarship on this question, see Roth, "Did Tertullian Possess a Greek Copy or Latin Translation of Marcion’s Gospel?,” 431-42; Schmid, Marcion und sein Apostolos, 40-59.

${ }^{9}$ As Quispel himself, decades after his original contribution, points out, despite the fact that his own conclusion "received little support after publication," the work of more recent scholarship "would seem to tip the balance back in favour of the thesis that Tertullian knew and used a Greek Marcion" (Gilles Quispel, "Marcion and the Text of the New Testament," VigChr 52 [1998]: 349-60, here 350 n. 4). Quispel is referring specifically to the works of Schmid, Marcion und sein Apostolos (see note 8) and John J. Clabeaux, A Lost Edition of the 
In deciding this matter, scholars have compared the citations of Marcion's texts reproduced in Tertullian's Adversus Marcionem with corresponding Gospel and Pauline citations elsewhere in Tertullian's corpus and then elsewhere in other extant Latin traditions. This nexus of data is then evaluated in terms of vocabulary and stylistic variation with an eye toward the genealogical and textual questions. Although much impressive and painstaking research has been conducted in this manner, the results of such a method are largely a matter of how one is predisposed to read the evidence - evidence that is tremendously variable and fragmentary. ${ }^{10}$ There is, however, a largely unexplored way forward in this debate, and it is to attend more closely to potential argumentative implications of a Latin versus Greek Vorlage and, specifically, to instances where arguments presented in Tertullian's Latin might unravel,

Letters of Paul: A Reassessment of the Text of the Pauline Corpus Attested by Marcion (Catholic Biblical Quarterly Monograph Series 21; Washington, D.C.: The Catholic Biblical Association of America, 1998).

${ }^{10}$ In relation to this methodological dilemma, consider Michael W. Holmes's characterization of the role of subjective judgment in textual criticism: "The claim that some methods are more 'objective' than others - in particular, the view that decisions based on external data are somehow more 'objective' (or at least less 'subjective') than those based on internal considerations - is largely illusory and misleading. With respect to both external and internal evidence, what counts as 'data' or 'evidence' is a theory-driven decision, and the choice of what data to follow is inescapably subjective" ("The Text of the Epistles Sixty Years After: An Assessment of Günther Zuntz's Contribution to Text-Critical Methodology and History," in Transmission and Reception: New Testament Text-Critical and Exegetical Studies [Jeffrey Childers and D.C. Parker, eds.; Text and Studies 4, $3^{\text {rd }}$ series; Piscataway, NJ: Gorgias, 2006], 89-113, here 103 n. 4). The same is true for investigations of Tertullian's sources. 
or at least become differently interesting, if retrojected into Marcion's Greek. Tertullian's discussion in Adversus Marcionem 5,18,1 of Eph 3:9, a passage Harnack identified as a locus classicus of Marcion's theology, is one such text.

\section{The Text of Ephesians (Laodiceans) 3:9 in Adversus Marcionem 5,18,1}

Although Tertullian's stated aim in Book 5 of Adversus Marcionem is to demonstrate the error of Marcion's theology on the basis of Marcion's own (purportedly) edited version of the Pauline letters - or, Tertullian would say, Marcion's own “mutilated” version of the Pauline letters - he nonetheless is keen throughout to comment on Marcion's editorial work - that is, Marcion's alleged practice of trimming the data to fit his own "heretical" ideas. ${ }^{11}$ For instance, just prior to his treatment of Eph 3:9 in 5,18,1, Tertullian discusses Marcion's

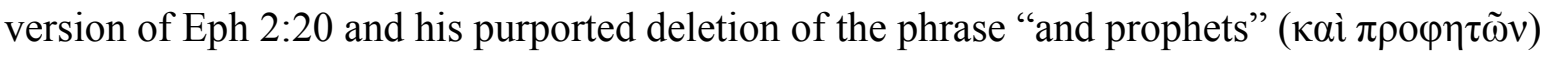
from that verse (see 5,17,16). ${ }^{12}$ The reason for Marcion's redaction here is, in Tertullian's eyes, uncomplicated. Marcion could not have Paul affirming that the Christian household of God is built on the foundation "of the apostles and prophets" because this would require him to admit that the Creator's own prophets are somehow foundational for Christ's church. Since the Creator and Christ are opposed deities, this cannot be. And so Marcion deletes what doesn't fit, or so Tertullian maintains.

In his analysis of Marcion's text of Eph 3:9 in 5,18,1, Marcion's editorial activity is again raised straightaway. Tertullian writes:

\footnotetext{
11 “Alleged" should be emphasized, for despite the posture of his argument, Tertullian has no certain knowledge of Marcion's Vorlagen nor of his intent.

${ }^{12}$ SC 483, 324, 155-60 Moreschini.
} 
De manibus haeretici praecidendis, non miror si syllabas subtrahit, cum paginas totas plerumque subducit. Datam inquit sibi Apostolus gratiam nouissimo omnium “inluminandi omnes, quae dispensatio sacramenti occulti ab aeuis in Deo, qui omnia condidit." Rapuit haereticus "in" praepositionem et ita legi fecit: "occulti ab aeuis deo, qui omnia condidit.",13

As for the heretic's hand in chopping, I am not astonished if he subtracts syllables when he deletes the majority of entire pages. The apostle says that to himself "last of all was given the grace to make all people see what is the dispensation of the mystery which from the ages has been hidden in [or by] the God who created all things." The heretic has taken away the preposition "in," and so it is made to read: "hidden from the ages from the God who created all things."

The accusation here is that by deleting a simple preposition from his text, ${ }^{14}$ Marcion has transformed the statement that the dispensation of the mystery "was hidden from the ages in [or by] the God who created all things" ${ }^{\prime 15}$ (occulti ab aeuis in Deo, qui omnia condidit) to the statement that it "was hidden from the ages from the God who created all things" (occulti ab aeuis deo, qui omnia condidit). Marcion's text (as Tertullian describes it) thus leaves the word deo in the same form and still reads it as an ablative (as opposed to a dative), but no longer governed by the preposition in. Presumably this would have been a key proof text for Marcion since it refers explicitly to the creator God (qui omnia condidit) and also describes this God as previously ignorant of the newly revealed Christian mystery (cf. Eph 3:3-6). Harnack, in fact, identified this text as Marcion's most infamous editorial erasure ("In 3,9 ist ${ }^{13}$ SC 483, 326,1-7 Moreschini.

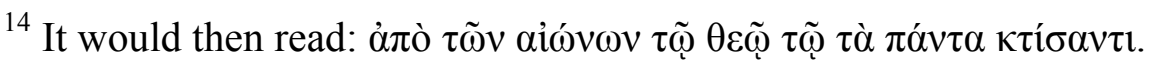

${ }^{15}$ Either a locative or an instrumental reading of $\dot{\varepsilon} v$ could be troublesome for a Marcionite. 
[Marcion's] berüchtigtste Streichung enthalten") and a locus classicus for his doctrine ("er ...erhielt so einen locus classicus für seine Lehre, dass die Heilsökonomie des guten Gottes dem Weltschöpfer von Urzeiten her verborgen gewesen sei”). ${ }^{16}$ Tertullian, like Harnack, apparently does not question the effect of Marcion's editing. He evidently concedes that the deo alone should be read as an ablative and not a dative and thus as now marking separation rather than agency or location. And so rather than contend with Marcion's new reading of this particular verse, he instead attempts to refute him by showing other ways in which this reading of "from God" is contradicted in the immediate context. ${ }^{17} \mathrm{He}$ therefore concludes that, though perhaps successful in isolation, Marcion's redaction of Eph 3:9 ultimately fails because it is inconsistent with Paul's reasoning in the near context of this verse. Thus again Marcion's mutilation is found deficient even on Marcion's own terms, or so Tertullian insists.

Returning to Marcion's text of Eph 3:9, notice how Tertullian's assessment of the situation makes perfect sense in Latin. With the prepositional phrase in deo, which Tertullian takes to be the Latin equivalent of what Paul actually wrote, Paul is affirming that the Creator has been the one hiding the dispensation of the Christian mystery that Paul now proclaims: it

\footnotetext{
${ }^{16}$ Harnack, Marcion (see note 1), 47.
}

${ }^{17}$ Judith M. Lieu helpfully characterizes Tertullian's argument here and its underlying motive: “Tertullian's detailed exposé of the lack of any logic in such a position turns on the unresolved question whether the principalities and powers of the following verse belong to the Creator or to the superior God; as he imagines first one answer, then another, and then, finally, portrays the heretic as compelled to change his position, suspicion grows that the entire debate has been set up by Tertullian himself to discredit an opposition who may not have recognised their own position at any point" (Marcion and the Making of a Heretic: God and Scripture in the Second Century [Cambridge: Cambridge University Press, 2015], 260). 
has been hidden in [or by] the God who created all things (occulti ab aeuvis in deo, qui omnia condidit). This would contradict Marcion's theology since it would require him to admit that the creator God somehow cooperated with Christ in concealing the sacramentum described in 3:9. Therefore, by deleting the simple preposition in, Marcion transforms the deo in the prepositional phrase in deo into an independent ablative marking separation ("from the God"). And so whereas the dative phrase in deo either locates the previously hidden sacramentum "in the God who created all things" or expresses the instrumentality of that God in concealing the sacramentum ("...hidden by the God who created all things"), the ablative deo marks the creator God as the one from whom the sacramentum was previously veiled (“...hidden from the God who created all things"). With the simple deletion of a preposition Marcion thus again bifurcates the Creator and Christ, or so the accusation goes.

There is, however, a problem (or at least a missed opportunity) in Tertullian's description of the situation here. The basic issue is that while occulti...deo qui omnia condidit can easily be read in Latin as "having been hidden from the God who created all things" with the form deo now standing alone as an ablative (or perhaps being coordinated with the preceding preposition $a b$ and so in parallel with the ab aeuis expression) - the Greek expression that presumably lies behind Marcion's emendation is not so easily read as Tertullian's Latin suggests:

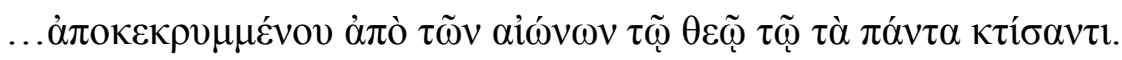

Since there is no ablative form in Greek, if Marcion indeed edited Paul's text as Tertullian

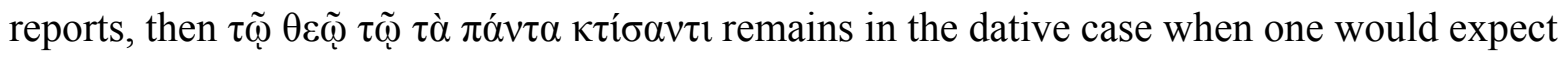

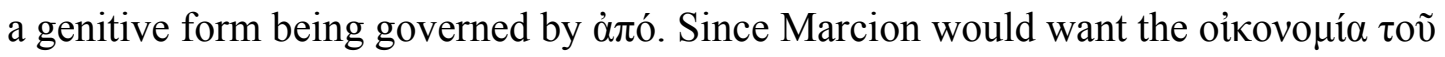

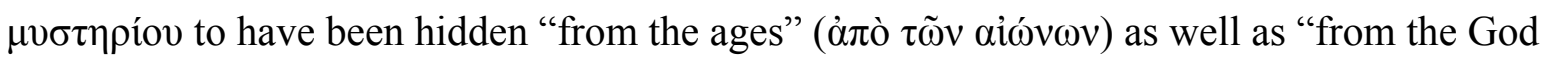

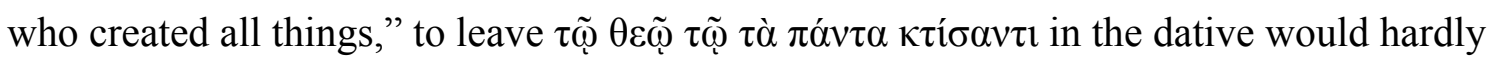


deliver such a reading. The simple deletion of the Greek preposition $\dot{\varepsilon} v$, therefore, fails to achieve the effect in Greek that Tertullian's Latin explanation suggests.

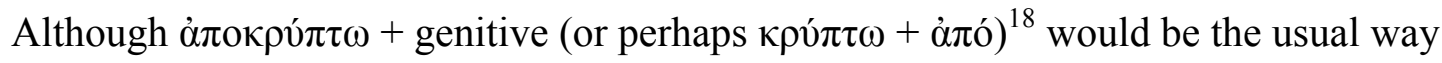
to express the "hidden from" idea in Greek, $\dot{\alpha} \pi$ oкрv́ $\pi \tau \omega$ + dative could possibly be taken as

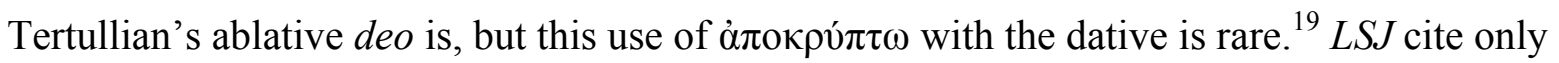

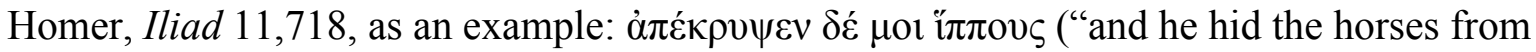
me"). But the $\mu \mathrm{ol}$ in this passage could just as easily, and perhaps more naturally, be taken as a dative of possession. This is in fact how Murray's LCL translation renders it: "hid away my horses." Another apparent instance of this construction is from Philo: $\tau$ ò $\delta \dot{\varepsilon} \alpha$ ťv $\gamma \mu \alpha \alpha$ ov̉ $\lambda$ íav

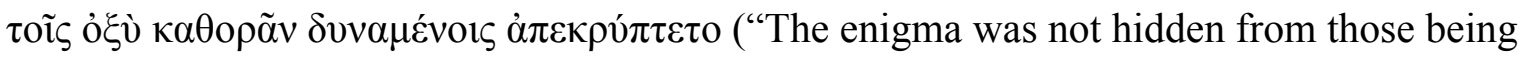
able to perceive with great quickness") (De somniis 2,3). ${ }^{20}$ Even clearer and, interestingly,

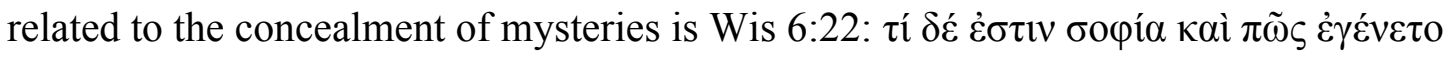

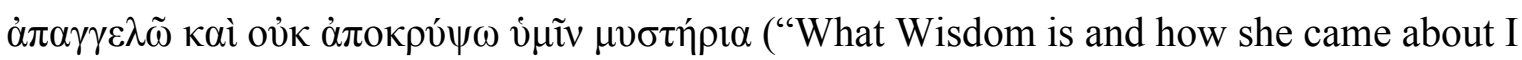
will declare, and I will not hide mysteries from you").

These examples demonstrate that it is perhaps grammatically possible to read Marcion's reconstructed Greek text as Tertullian assumes - that is, as indicating that the dispensation of the mystery was hidden from the creator God - but it is certainly not the most

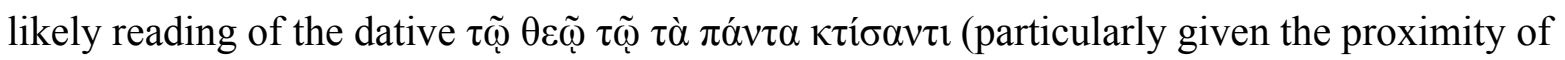
the immediately preceding àđó phrase), nor does it in any way diminish the possibility of

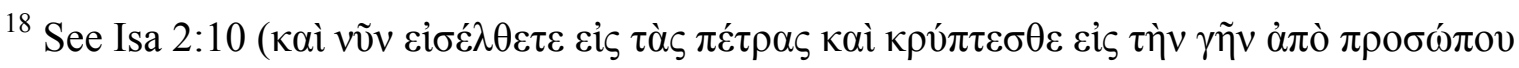

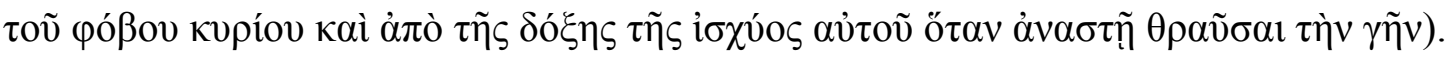

${ }^{19}$ It would perhaps be classified as a dative of respect or reference.

${ }^{20}$ Jeffrey Henderson, ed., Philo: Volume V (Loeb Classical Library 275; Cambridge, MA: Harvard University Press, 1934), 444,1-2.
} 
reading the dative as though the preposition $\dot{\varepsilon} v$ were still in place. ${ }^{21}$ The shift from the

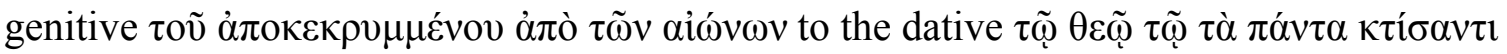
still suggests a shift in sense from separation (àđò $\tau \tilde{\omega} v \alpha i \omega ́ v \omega v)$ toward location or

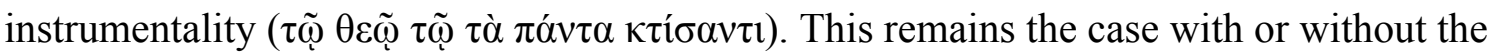

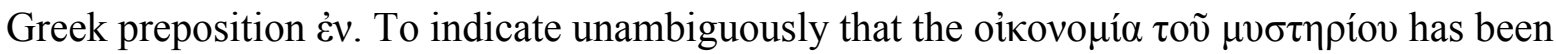
hidden "from the God who created all things" would require the genitive. It is worth pointing out that other manuscripts, such as Codex Sinaiticus ( $\left.\aleph^{*}\right)$ (see also 614 and 2412), also lack the $\dot{\varepsilon} v$ - thus agreeing with Marcion's presumed text. ${ }^{22}$ Although the preposition was eventually added to Sinaiticus by a fifth to seventh century corrector (the $\mathrm{C}^{\mathrm{a}}$ corrector), it was still passed over as unproblematic by multiple other correctors prior to this emendation. ${ }^{23}$ For

${ }^{21}$ In the end, we cannot be certain whether or not Marcion's Greek version of Eph 3:9 just omitted the $\dot{\varepsilon} v$ or perhaps included other changes as well. That Marcion did omit the $\dot{\varepsilon} v$ is, however, perhaps likely. Clabeaux, A Lost Edition (see note 9), 32, identifies a pattern to the removal of $\dot{\varepsilon} v$ in Marcion's text of Ephesians (Laodiceans). It is omitted in Eph 2:15 $(5,17,5)$; $3: 9(5,18,1) ; 6: 14(3,14,4)$; and $6: 15(3,15,4)$.

${ }^{22}$ Lieu points out that the Dialogue of Adamantius (De Recta in Deum Fide) retains the in and uses this text against the Marcionite reading (Marcion and the Making [see note 15], 260 n. 84).

${ }^{23}$ As Schmid notes, "Die Auslassung dieser Präposition ermöglicht zwar eine Interpretation dieses Textes in dem Sinne, wie Tertullian es Schildert. Allerdings deutet die Tatsache, dass auch andere HSS (S* 614 2412) die Präposition auslassen, darauf hin, dass dies entweder nicht die einzige Interpretationsmöglichkeit dieses Textes ist oder aber, dass der marcionitische Text nicht der einzige Text war, der eine solche Interpretation vertreten 
the multiple scribes and correctors associated with the early history of a manuscript like Codex Sinaiticus, the absence of the $\dot{\varepsilon} v$ in Eph 3:9 did not entail a Marcionite reading.

\section{Conclusion}

What then is one to make of Tertullian's argument and the question of whether he was reading Marcion's text of Eph 3:9 in Latin or Greek? Assuming that Tertullian is accurately reporting what he sees, and that what he sees accurately corresponds to what Marcion produced, there would seem to be two leading possibilities. The first is that Tertullian was reading Marcion in Greek and that Marcion's Pauline text did lack the proposition śv. If this is the case, it is a surprising oversight of the problems for Marcion's own reading that would still remain in Marcion's Greek version (if we accept Tertullian's claims about Marcion's reading and his diagnosis of Marcion's editorial intent). Tertullian would have missed a perfect opportunity to exploit the fact that Marcion's own text again witnesses against him and that his own editorial activity again collapses upon itself. Instead of admitting that Marcion's deletion of the Latin in transforms Paul's statement into one in which the dispensation of the mystery is hidden from the creator God - thus still reading deo as an ablative - he could have easily insisted that the same deo be read as a Latin dative, like the Greek dative, and so as indicating location or instrumentality. In other words, Tertullian could have pointed out the foolishness of Marcion's attempt by arguing that Marcion's

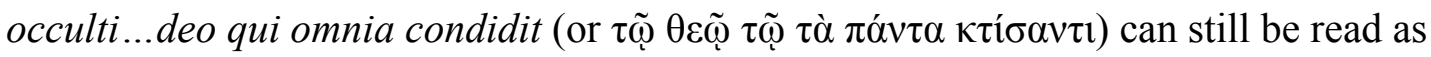
indicating the creator God's role in concealing the mystery. He could then again berate Marcion for his ineptness as an editor and for the fact that even Marcion's mutilated Paul again defies Marcion's theology. And he could have done all this easily enough in Latin

konnte. Im übrigen kann die Präposition auch mechanisch ausgefallen sein; sie ist nicht als genealogisch signifikant zu beurteilen” (Marcion und sein Apostolos [see note 8], 112-13). 
without burdening the reader by delving into the niceties of comparative grammar. ${ }^{24}$ Given that Tertullian's primary argumentative aim is to defeat Marcion even on the terms of Marcion's own text, it is telling that he does not exploit this opportunity.

The second option is that Tertullian only had access to Marcion in Latin translation, as Harnack some time ago supposed. Tertullian thus simply accepts that the absence of the Latin in leaves the deo unchanged in the ablative. He then attributes editorial intent to Marcion and attempts to refute his new reading by other means. The oversight is still there, but it becomes less surprising. Tertullian of course knows the Greek text of Paul's letters. He in fact refers to the Greek of Eph 1:10 at the very outset of his treatment of Ephesians (Laodiceans) in $5,17 .{ }^{25}$ Tertullian was capably bilingual and is even known to have composed

${ }^{24}$ It is worth pointing out that Tertullian is not reluctant to explain or to appeal to Greek in Adversus Marcionem. At times he deems it necessary. See e.g. 1,13,4 (SC 365, 162,33-34 Braun) (secundum sonum Graecorum uocabulorum); 2,9,1 (SC 368 64,5-6 Braun) (quod Graeca scriptura signauit); 2,24,8 (148,79-80 B.) (Nam et in Graeco sono); 3,22,6 (SC 399 192,50-51 Braun) (Ipsa est enim littera Graecorum Tau, nostra autem T, species cruces...); 4,8,4 (SC 456 108,32-33 Moreschini) (Portare autem Graeci etiam pro eo solent ponere quod est tollere); 4,14,1 (174,3-4 M.) (sic enim exigit interpretatio uocabuli, quod in Graeco est...).

${ }^{25}$ When he glosses the Greek word $\alpha v \alpha \kappa \varepsilon \varphi \alpha \lambda \alpha \iota \omega \sigma \alpha \sigma \theta \alpha \mathrm{l}$ in Eph 1:10 as recapitulare, he explains that this is "the sense of that word in Greek" (sicut uerbum illud in graeco sonat) $(5,17,1)(308,10-11$ M.). 
treatises in Greek. ${ }^{26}$ But if his primary text of Marcion is a Latin Apostolikon, it is to be expected that he would be thinking primarily in Latin terms - terms in which the weaknesses in Marcion's supposed Greek deletion would be less apparent. Though he could still be faulted for not exploiting weaknesses that become more apparent in the Greek, the reason for this failure becomes more explicable.

To return to the question of this essay - "Did Tertullian Read Marcion in Latin?" - at the very least we can conclude that this matter is not one of mere historical curiosity. The question of Greek or Latin Vorlagen is at times integral to the inner workings of Tertullian's own argument and deserves more serious consideration in scholarly work on this text. ${ }^{27}$ But can the question be answered? While I would encourage more attention be given to the potential implications of Greek or Latin source texts, I would urge caution in making absolute

${ }^{26}$ See De corona 6,3 (PL 2, 83C Migne); Adversus Praxean 3,22-25 (ed. Ernest Evans, Tertullian's Treatise Against Praxeas: The Text edited, with an Introduction, Translation, and Commentary [London: SPCK, 1948], 91,22-25);

${ }^{27}$ Lieu briefly notes the significance of this issue in relation to Tertullian's treatment of Marcion's text of Gal 4:22-26. As she explains, “the force of [Tertullian's] explanation at this point would differ according to whether he is working from the Greek text of Marcion's 'Apostolikon' or from on already translated into Latin" (Marcion and the Making, 249). In his discussion of the "elements" in Gal 4:8-9, Lieu submits that Tertullian's appeal to the meaning of elementa among the Romans "might suggest that he is arguing from a Latin version of Galatians" (Marcion and the Making, 257 n. 77). As for Lieu's own judgment on the matter, although she does not proffer a "firm solution," she admits that this "issue is of obvious importance for any detailed reconstruction of Marcion's text" (Marcion and the Making, 193). 
judgments about a single Greek or Latin Vorlage. Whatever version (or versions!) of Marcion's Apostolikon Tertullian had in his possession, ${ }^{28}$ he also had alternative Greek and presumably Latin Pauline manuscripts for comparison. It is in the process of comparison that he forms judgments about the intentions behind Marcion's editorial procedure. In the case of Eph 3:9, Tertullian ascribes editorial intent to Marcion when he observes that Marcion's text differs from his own. He thus assumes the priority or integrity of his own textual tradition and that, where Marcion's differs, an authentic Pauline tradition has been redacted. But there is no way for us (or Tertullian, for that matter) to know the relationship between Marcion's text and the Pauline traditions that stand behind it. Perhaps Marcion's textual precursors, like Codex Sinaiticus (※), also lacked the $\dot{\varepsilon} v$ and so represent an older reading. Perhaps texts known to Tertullian with the $\dot{\varepsilon} v /$ in reflect a subsequent "orthodox corruption." Perhaps Marcion's Greek text of Eph 3:9 contained other alterations which have become undetectable in Latin translation. Alongside these possibilities exists an additional range of complexity. The textual world of antiquity is a scattered network of evolving and eroding literary artifacts. Manuscripts are copied and miscopied, translated and re-translated, interpolated and erased, corrected and otherwise contaminated, or variously marred by time and accident. When it comes to the presence or absence of a two-letter Greek preposition in a text we only learn about several decades later in the Latin description of a bitter polemicist, the way forward - and the way forward in analyses of Tertullian's interaction with Marcion more

${ }^{28}$ It is not impossible that Tertullian had multiple versions of the Apostolikon, perhaps in both Latin and Greek. Lieu submits that Tertullian likely did not have access to Marcion's Apostolikon until he came to write Books 4 and 5 of Adversus Marcionem (Marcion and the Making, 235). She observes that in Adversus Marcionem 3,5,4 Tertullian follows the "catholic" order of Paul's letters and refers to Ephesians as Ephesians, not Laodiceans (235 n. 3). Such evidence is interesting but slim. 
generally - is not to refuse this complexity and always rule one way or the other on the question of a Greek or Latin Vorlage. The way forward is to welcome the unknowns of the situation by engaging the multitude of textual, rhetorical, and theological dynamics potentially at work in the thick knot of possibilities. 